\title{
BUTTERFLIES \\ FROM THE SOUTHEASTERN MACKENZIE DISTRICT, N.W.T.
}

by WAYNE C. HARRIS*

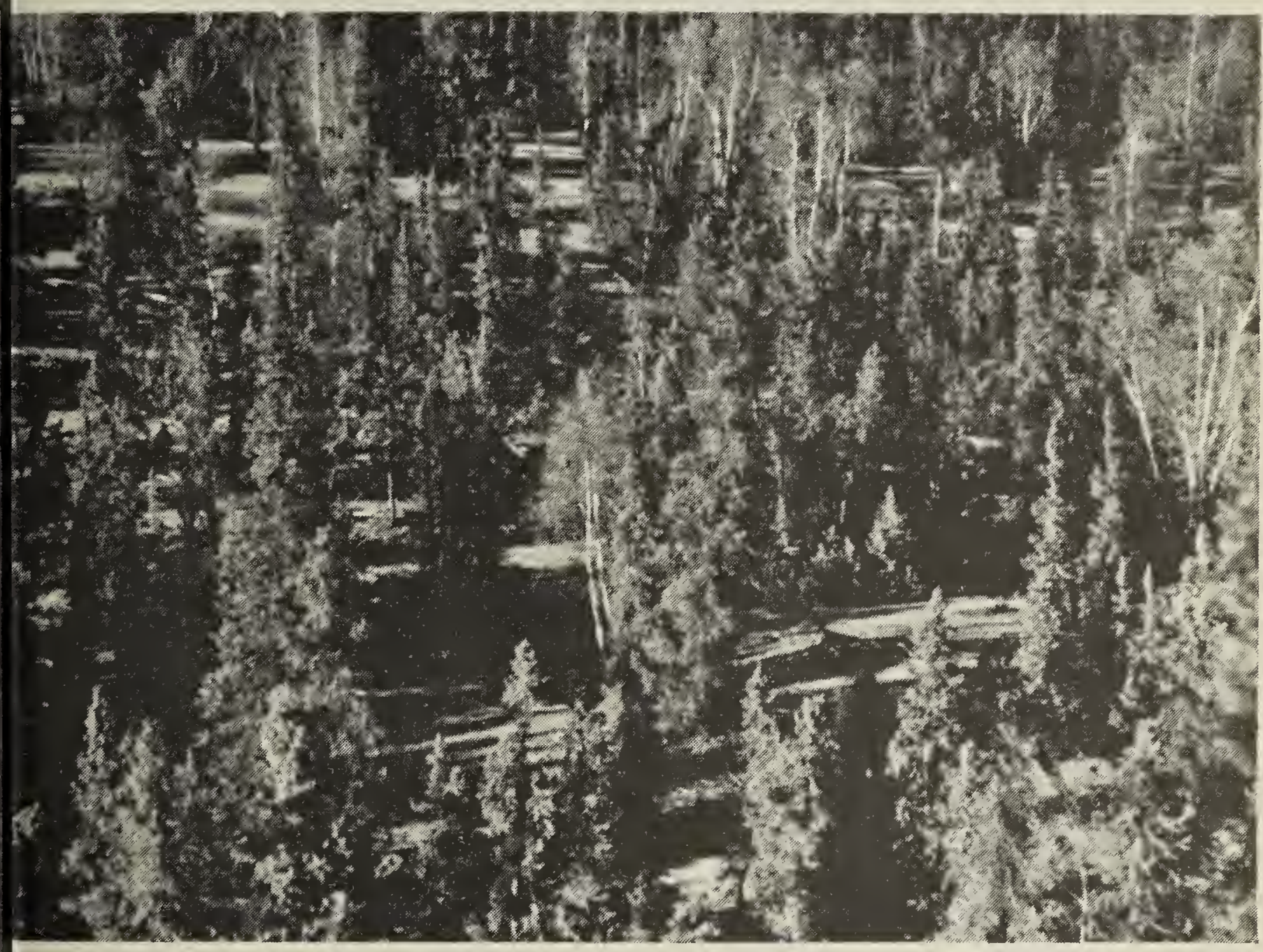

Upland Lichen woodland with Black Spruce, White Spruce, scattered Paper Birch and Jack Pine.

The following notes were collected hile in the southeastern part of the District of Mackenzie from June 3 to ugust 16,1974 . During this time four reas were visited: Porter Lake $\left(108^{\circ}\right.$ $\left.0^{\prime}, 61^{\circ} 41^{\prime}\right)$ from June 5 to July 3 , nowdrift $\left(110^{\circ} 48^{\prime}, 62^{\circ} 24^{\prime}\right)$ from July to July 20 , Forestry Lake ( $105^{\circ} 30^{\prime}$, $0^{\circ} 56^{\prime}$ ) from July 24 to August 10 and t. Smith $\left(111^{\circ} 52^{\prime}, 60^{\circ} 00^{\prime}\right)$ from June to 5 , July 3 to 5 , July 20 to 24 and ugust 15 and 16.

Box 93, Raymore, Sask. S0A 3 J0
Snowdrift, Porter Lake and Forestry Lake are located on the Precambrian Shield in the Northwestern Transition Boreal Forest Region. ${ }^{2}$ This is the forest edge bordering the tundra in which areas of bog, muskeg and barren rock are intermixed with open stands of Black Spruce (Picea mariana) with lesser amounts of Jack Pine (Pinus banksiana), Tamarack (Larix laricina), White Spruce (Picea glauca) and Paper Birch (Betula papyrifera). Ground cover is characteristically light coloured lichens, of which Cladonias, 


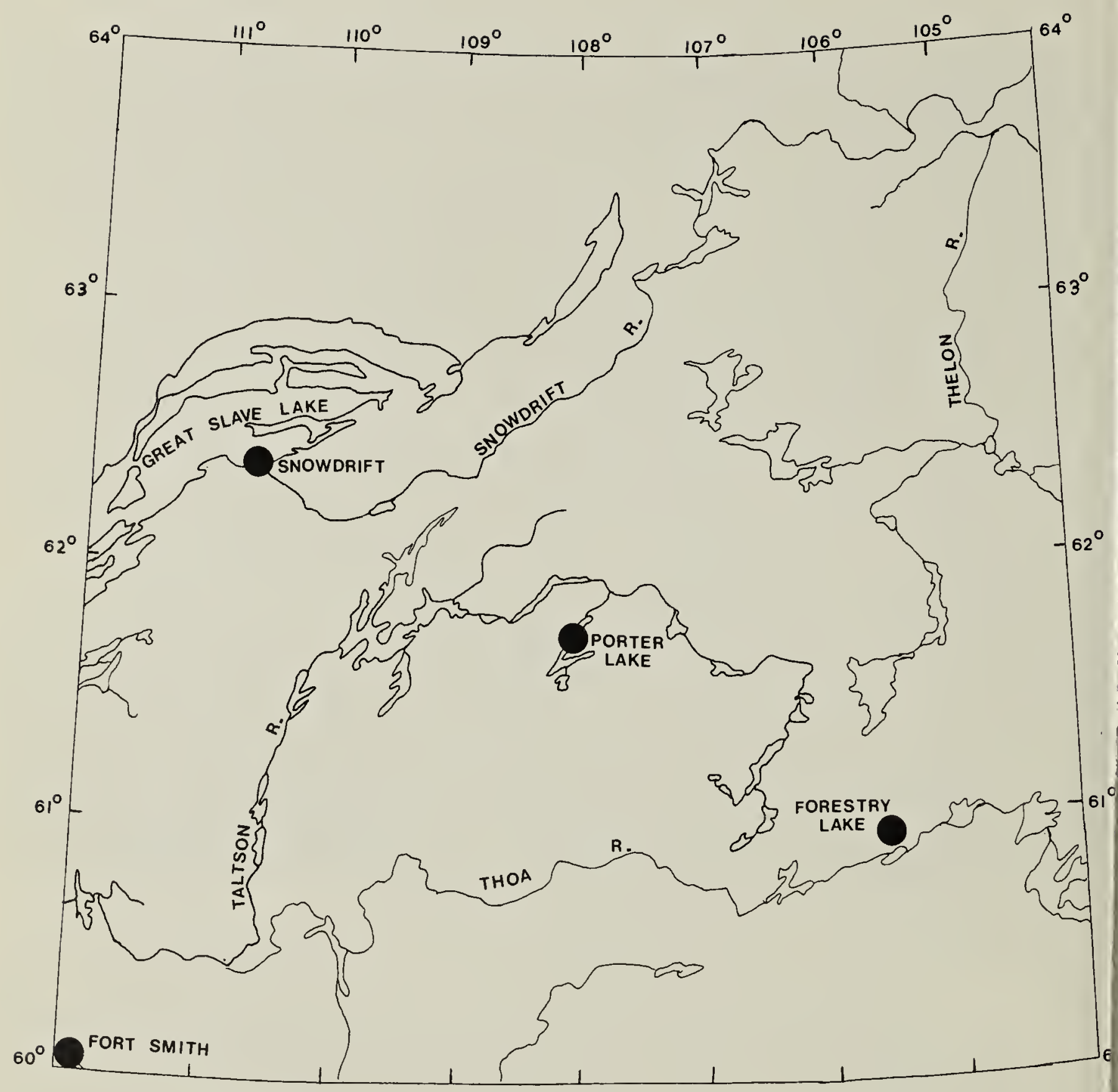

Study area and collection sites.

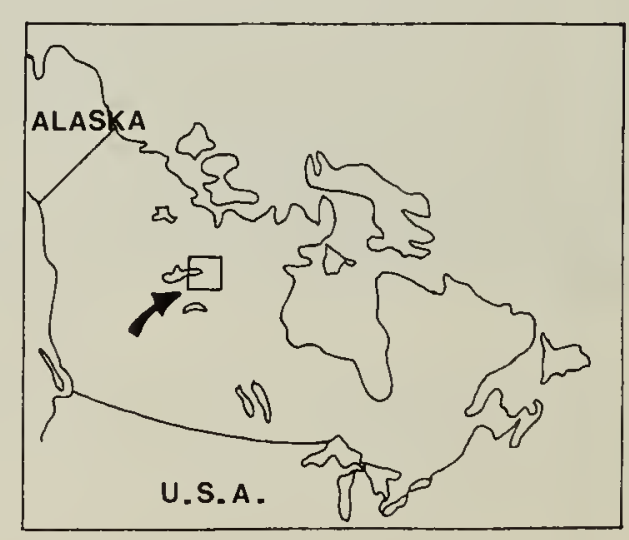




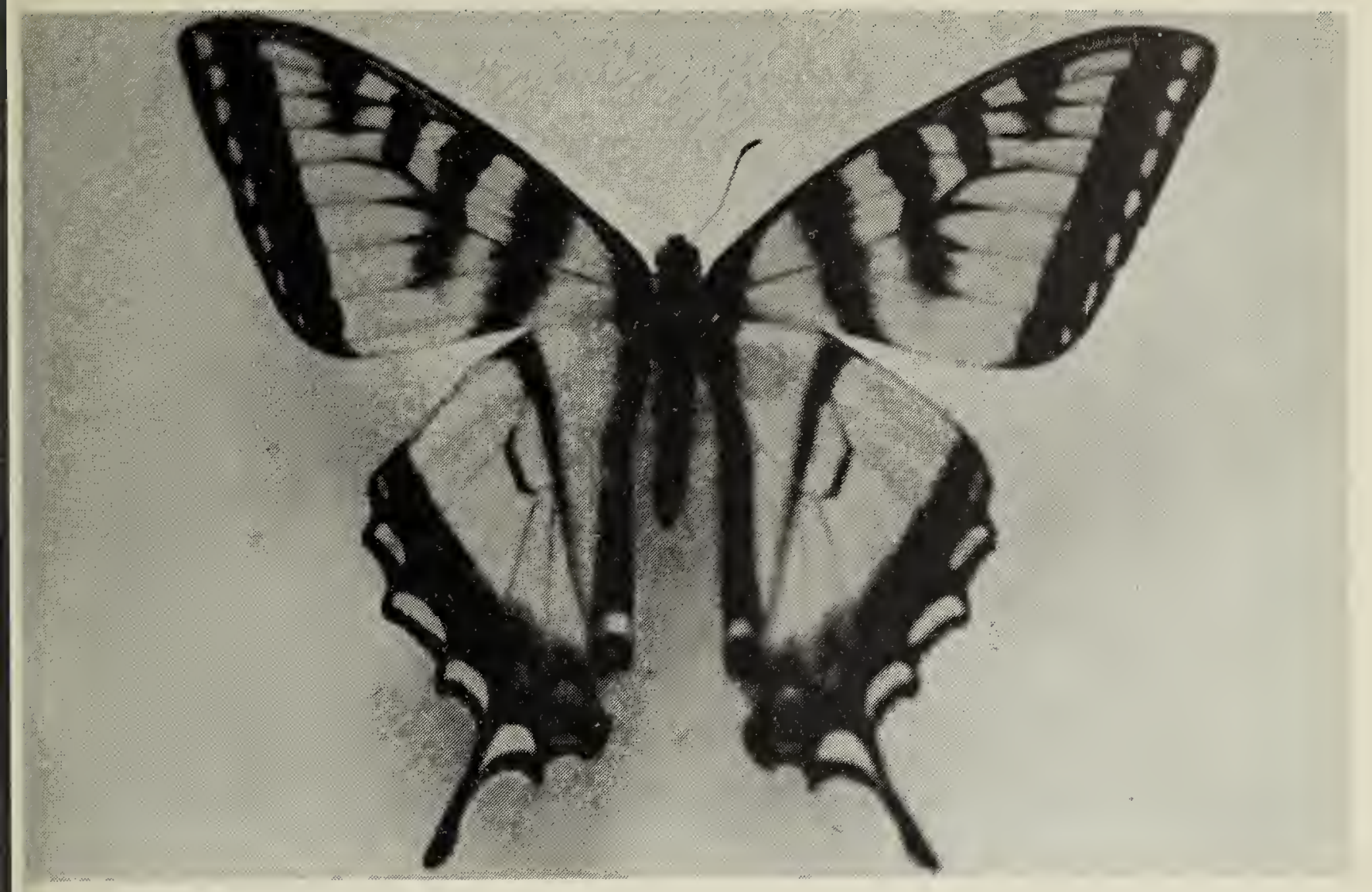

nadian Tiger Swallowtail (x 1.0)

Wayne C. Harris

etrarias and Stereocaulons are the ominants."

Ft. Smith, located just off the uthern edge of the Shield, is in the Ipper Mackenzie Forest Region." A losed canopy of White Spruce, Tremling Aspen (Populus tremuloides) and ick Pine occurs on the uplands with lack Spruce being the dominant in wer areas.

Butterflies were uncommon in this gion. Almost all of the species noted ere found in the month of June and bservations were almost non-existent - July and August. Butterflies may be ncommon here because of a lack of litable plants to feed on.

Temperatures were about normal or the summer, with the average high $5.70^{\circ} \mathrm{F}$. Precipitation was above noral for the summer.

I would like to thank E. Johnson and Lamont for their assistance in eparing this note and R. Hooper for s assistance in identifying the pecimens.
Annotated List

A total of 13 species was recorded during the summer; specimens were not collected of all species. However, an individual was caught, identified and released for all species reported here. The nomenclature follows Butterflies of Saskatchewan.' This was also used for identification of all the species found. Species for which a specimen was collected are marked with an asterisk $\left(^{*}\right)$.

*PERSIUS DUSKY WING (Erynnis persius fredericki Freeman). On June 5, two individuals thought to be this species were seen at Ft. Smith. On July 11 a single specimen was collected at Snowdrift. Habitat at Fort Smith was a grassy hill along the Slave River with Trembling Aspen and White Spruce. At Snowdrift it was seen on a moist north-facing slope vegetated with White Spruce and a ground cover of Feather Moss (Pleurozium schreberi).

CANADIAN TIGER SWALLOWTAIL (Papilio glaucus canadensis Rothschild 


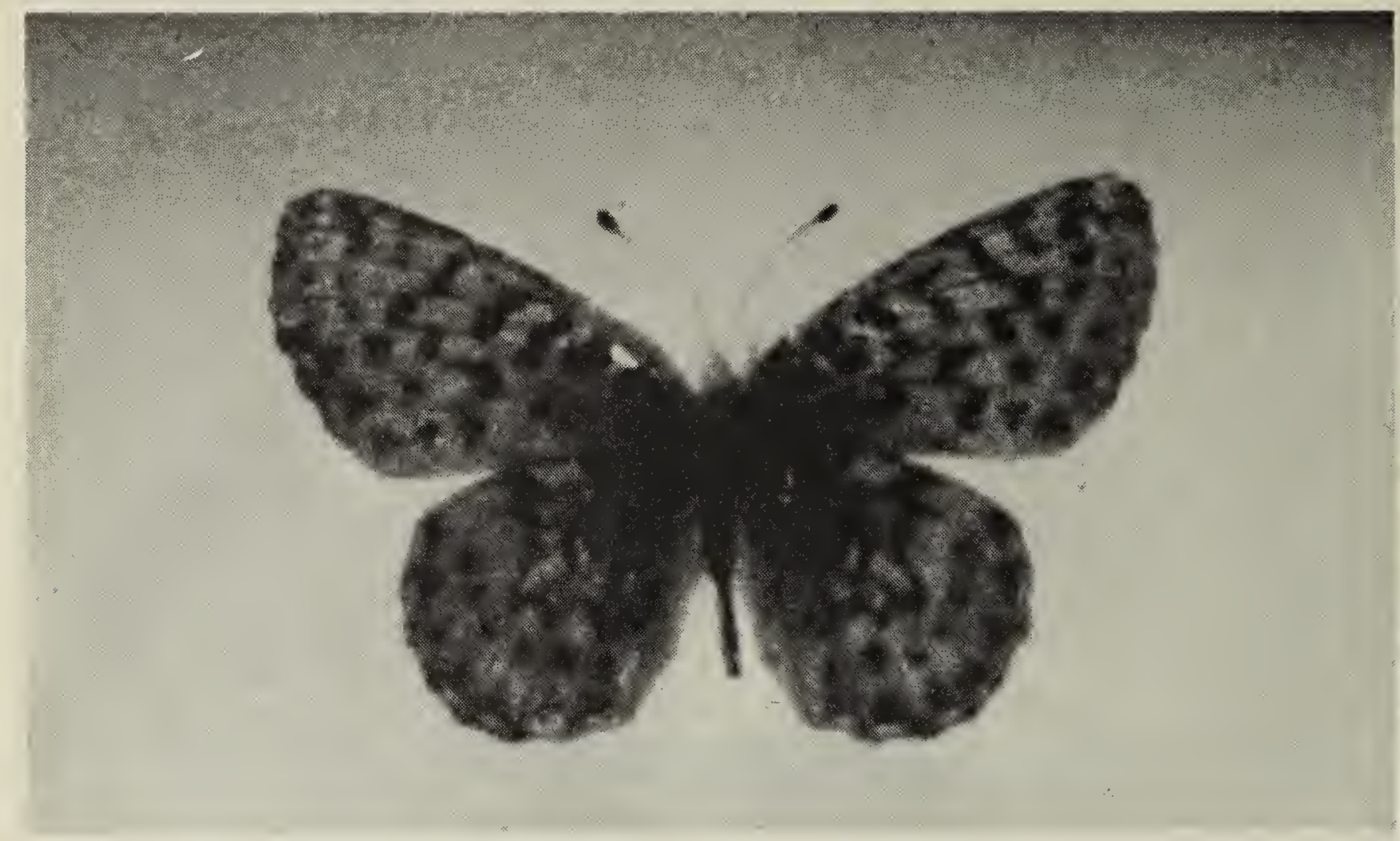

Purple Lesser Fritillary (x 1.85)

Wayne C. Harr

and Jordan). A single individual at Ft. Smith on June 5 and two along a sandy beach at Porter Lake on June 19 were the only sightings.

PALAENO SULPHUR (Colias palaeno chippewa Edwards). This species was observed once at Porter Lake on June 27 . The habitat was an area which had been burned in 1972 along a bedrock ridge at least 500 meters from the nearest bog or meadow.

\section{* SILVERY BLUE (Glaucopsyche} lygdamus couperi Grote). A group of five was seen at Ft. Smith on June 5. A single specimen, was collected. The only other record was of two seen at Porter Lake on June 11. In both locations this species was found in small open areas surrounded by Black Spruce and White Spruce with a ground cover of lichens and with no flowers in the immediate vicinity.

* SPRING AZURE (Celastrina argiolus lucia Kirby). This species was recorded intermittently at Porter Lake from June 11 to June 20 with a maximum of four seen on one day. Single specimer were collected at Porter Lake on Jur 11 and June 20. The habitat was sma clearings along an esker vegetated wi Black and White Spruce. Prick Saxifrage (Saxifraga tricuspidata) w the common flower.

WHITE ADMIRAL (Limenitis arthem rubrofasciata Barnes and $\mathrm{McDu}$ nough). The only record was a sing individual observed at Forestry La on August 2. Habitat was a sandy esk vegetated with mature White Spruce

RED ADMIRAL (Vanessa atalanta Li naeus). On June 27 one visited $t$ buildings around our camp at Por Lake. This individual was observ throughout most of the day as it $\mathrm{fl}$ around the edges of a small b vegetated with Sphagnum a flowering Labrador Tea (Led $t$ decumbens). The only plant spec which it was observed landing on $v$ Labrador Tea. The known food pla Stinging Nettle (Urtica gracilis)', is it found in the Porter Lake area. 


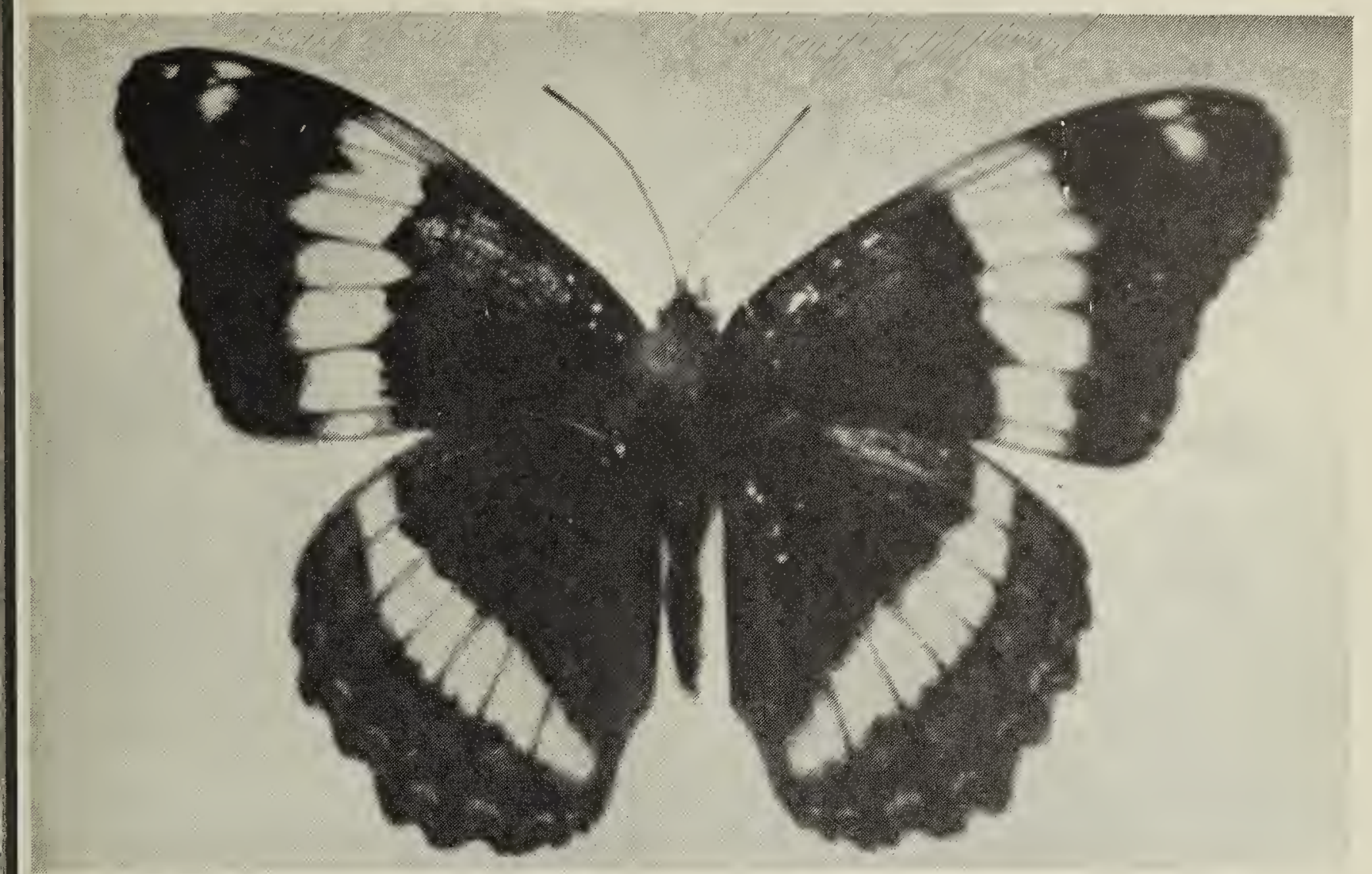

hite Admiral (x 1.6)

Wayne C. Harris

MILBERT'S TORTOISE SHELL ( Nymhalis milberti Godart). A single pecimen was collected at Fort Smith $n$ June 5 in a small grassy clearing.

OURNING CLOAK (Nymphalis antiopa innaeus). Single individuals were fen at Porter Lake on June 14 and Ine 19. The habitat for both was a fast owing small stream bordered by lack Spruce. The only other obseration was of a single individual seen Forestry Lake on July 31 along a indy esker.

GREEN COMMA (Polygonia faunus lsticus Edwards). This species was en only at Porter Lake. On June 21 veral were observed along a small pring flowing through the boulders hder a mature White Spruce canopy.

FRIEJA FRITILLARY (Boloria freija hunberg). This was by far the most pmmon butterfly species found in the ea. Scores were seen at Porter Lake n June 12 and this species remained pmmon for the remainder of June. hree specimens were collected on
June 11 and one on June 19. Habitat in all cases was dry uplands along sandy eskers or bedrock outcroppings.

*PURPLE LESSER FRITILLARY (Boloria titania grandis Barnes and MCDunnough). A single specimen was collected at Porter Lake on August 13 on an esker vegetated with open White Spruce and a lichen ground cover.

* MANCINUS ALPINE (Erebia disa mancinus Doubleday). Small numbers were seen at Porter Lake in Black Spruce bogs. On June 11 a single specimen was collected and the next day three more were seen at the same location. At a different location on the lake on June 19 one was found dead and several others seen.

'HOOPER, R. R. 1973. Butterflies of Saskatchewan. Sask. Dept. of Natural Resources, Regina $216 \mathrm{pp}$.

'ROWE, J. S. 1972. Forest Regions of Canada. Dept. of the Environment, Canadian Forestry Service, Publication No. 1300. 172 pp. 